\title{
ANALISIS STRUKTUR TEKS PROSEDUR SISWA KELAS VII SMPN 7 KOTA BENGKULU
}

\author{
'Sandiya Desti Ayunisyah; ${ }^{2}$ M. Arifin; ${ }^{3}$ Didi Yulistio \\ Program Studi Pendidikan Bahasa Indonesia Jurusan Pendidikan Bahasa dan Seni \\ FKIP Universitas Bengkulu
}

Abstrak

\section{Korespondensi: sandiyadestiayunisyah@gmail.com}

Tujuan penelitian ini mendeskripsikan struktur teks prosedur yang berupa judul, tujuan, alat/bahan, dan tahapan yang ditulis siswa kelas VII C SMPN 7 Kota Bengkulu. Metode yang digunakan adalah metode deskriptif dengan pendekatan kualitatif. Teknik yang digunakan dalam penelitian ini adalah teknik tes. Teknik analisis data yang digunakan adalah membaca, mengelompokkan, menabulasi, menginterpretasi, dan menyimpulkan. Berdasarkan hasil penelitian, diketahui sebagian besar judul teks prosedur yang ditulis berupa cara melakukan atau menggunakan sesuatu dan judul yang ditulis sesuai syarat judul yang baik. Seluruh tujuan teks prosedur ditulis berupa paragraf pengantar yang menyatakan tujuan penulisan dan menggunakan pilihan kata yang menarik. Sebagian besar bahan/alat teks prosedur ditulis berupa daftar rincian. Bahan/alat sebagian ditulis dengan ukuran yang rinci dan akurat sebagian tidak, dan tidak ditulis dengan ukuran yang rinci dan akurat. Sebagian besar tahapan teks prosedur menggunakan bentuk penomoran pada setiap langkah dan terdapat penggunaan kata penghubung waktu, kata penghubung tujuan, kata penghubung urutan, kalimat perintah dan kalimat larangan.

Kata Kunci: analisis, struktur teks, teks prosedur

\section{Abstract}

The purpose of this study is to describe the structure of the procedure text in the form of titles, objectives, tools/materials, and stages written by students of class VII C Students of 7th Middle School in Bengkulu City. The method used is descriptive method with a qualitative approach. The technique used in this study is a test technique. The data analysis technique used is reading, grouping, tabulating, interpreting, and concluding. Based on the results of the study, it is known that most procedure text titles are written in the form of how to do or use something and the title written according to the terms of the title is good. The entire purpose of the procedure text is written in the form of an introductory paragraph stating the purpose of writing and using a choice of interesting words. Most of the procedure text material/tools are written in the form of a detailed list. Materials/tools are partially written in a detailed and accurate size, some are not, and are not written in detailed and accurate measurements. Most stages of the procedure text use the numbering form at each step and there are uses of time conjunctions, conjunctive goals, conjunctions of order, command sentences and prohibited sentences.

Keywords: analysis, text structure, procedure text 


\section{PENDAHULUAN}

Menulis merupakan salah satu keterampilan berbahasa yang harus dimiliki setiap orang. Menurut Susetyo (2014:1) menulis merupakan kegiatan untuk melahirkan pikiran atau perasaan. Melalui keterampilan menulis, seseorang dapat menuangkan ide dan pikirannya. Menulis bukan sesuatu hal yang baru, namun bagi sebagian orang, menulis merupakan kegiatan yang sangat sulit, terlebih bagi penulis pemula. Hal itu disebabkan dalam menulis dibutuhkan keterampilan yang kompleks. Menulis bukan semata-mata menuangkan ide atau gagasan ke dalam simbol-simbol grafis, melainkan cara berkomunikasi yang melibatkan proses berpikir. Bahkan sebelum menulis, otak sudah bekerja, mencari, memilih, merumuskan dan menggabungkan kata-kata atau gagasan sehingga memiliki makna yang dapat dipahami orang lain. Sering seseorang bisa berbicara, tetapi tidak bisa menulis kembali apa yang dibicarakannya. Sebaliknya, ada orang yang pandai menulis, tetapi tidak bisa mengungkapkan apa yang ditulisnya secara lisan.

Menurut Saddhono dan Slamet (2014: 151) pada dasarnya menulis itu, bukan hanya berupa melahirkan pikiran atau perasaan saja, melainkan juga merupakan pengungkapan ide, pengetahuan, ilmu dan pengalaman hidup seseorang dalam bahasa tulis. Oleh karena itu, menulis bukanlah merupakan kegiatan yang sederhana dan tidak perlu dipelajari, tetapi justru dikuasai. Mengingat pentingnya pengembangan kemampuan memahami dan menulis, pembelajaran tentang menulis pun diberikan kepada peserta didik, baik tingkat sekolah menengah pertama maupun atas. Pembelajaran menulis sudah diterapkan dari Kurikulum 1975, 1984, 1994, 2004 (KBK), 2006 (KTSP) sampai kurikulum 2013. Dalam Kurikulum 2013 pembelajaran menulis menggunakan teks sebagai sarananya dan pembelajaran tersebut disebut dengan pembelajaran berbasis teks. Tujuan pembelajaran berbasis teks adalah agar peserta didik mampu memahami dan memproduksi teks. Keterampilan memahami berkaitan dengan kemampuan membaca dan menyimak, sedangkan keterampilan memproduksi berkaitan dengan membicarakan dan menulis teks.

Dengan pembelajaran berbasis teks dalam Kurikulum 2013, bahasa Indonesia diajarkan bukan sekadar sebagai pengetahuan bahasa, melainkan teks yang mempunyai fungsi. Selain itu, dengan adanya pembelajaran berbasis teks dapat menjadikan peserta didik memahami serta mampu menggunakan teks sesuai dengan tujuan teks yang dipelajarinya. Menurut Mahsun (2014: 95) perancangan pembelajaran bahasa Indonesia berbasis teks juga memberi ruang pada peserta didik untuk mengembangkan berbagai jenis struktur berpikir karena setiap teks memiliki struktur berpikir yang berbeda satu sama lain. Semakin banyak jenis teks yang dikuasai, maka semakin banyak struktur berpikir yang dikuasai peserta didik. Lebih lanjut Mahsun (2014:99) menjelaskan bahwa pembelajaran teks mampu mengembangkan kemampuan berpikir peserta didik. Dengan satu topik tertentu, peserta didik dapat dilatih mengemukakan pandangannya tentang topik itu dalam berbagai cara.

Priyatni (2014:68) menyatakan bahwa pada jenjang SMP/MTs terdapat 14 jenis teks, yaitu (1) teks hasil obeservasi, (2) teks tanggapan deskripstif, (3) teks eksposisi, (4) teks eksplanasi, (5) teks cerita pendek, (6) teks cerita moral, (7) teks ulasan, (8) teks diskusi, (9) teks cerita prosedur, (10) teks cerita biografi, (11) teks eksemplum, (12) teks tanggapan kritis, (13) teks tantangan, (14) teks rekaman percobaan. Salah satu teks yang di pelajari peserta didik pada jenjang SMP tepatnya pada kelas VII adalah teks prosedur. 
Teks prosedur menyajikan sejumlah informasi tentang petunjuk untuk melakukan atau menggunakan sesuatu dengan langkah-langkah yang urut.

Teks prosedur ini sangat sering ditemui pada kehidupan sehari-hari. Contohnya, ketika menonton acara televisi terdapat tayangan memasak atau cara mencuci pakaian dengan mesin cuci, teks yang ada pada kemasan mi instan, buku manual alat, buku resep atau suatu produk (sampo, sabun cair, dsb.). Teks prosedur menurut Harsiati dkk. (2017:81) digunakan sebagai upaya untuk mewariskan budaya. Dari generasi ke generasi, warisan leluhur berupa budaya bangsa diajarkan secara turun temurun melalui petunjuk lisan maupun tertulis. Meski tidak sempat mengamati, semua produk budaya dan cara membuatnya tetap dapat dituangkan dalam bentuk teks prosedur. Produk-produk kreasi dan karya peserta didik dapat ditularkan dan disebarkan dengan cara menuliskan cara membuat atau cara melakukannya. Dalam kehidupan sehari-hari sering ditemui teks petunjuk, panduan, atau instruksi. Teks jenis ini akan sangat membantu orang dalam memahami hal yang belum diketahuinya, sehingga siswa dituntut untuk dapat menulis teks prosedur.

Menurut Kosasih dan Kurniawan (2018: 33) teks prosedur adalah teks yang menyajikan paparan penjelasan tentang cara melakukan sesuatu dengan sejelas-jelasnya. Keberadaan teks semacam itu sangat diperlukan oleh seseorang yang akan mempergunakan suatu benda atau melakukan kegiatan yang belum jelas cara penggunaannya. Menurut Mahsun (2014:30) teks prosedur adalah teks yang bertujuan untuk memberikan pengarahan atau pengajaran tentang langkah-langkah sesuatu yang telah ditentukan. Teks prosedur berisikan suatu pengamatan ataupun percobaan, lebih lanjut Mahsun menjelaskan bahwa teks prosedur memiliki struktur berpikir: judul, tujuan, daftar bahan, urutan tahapan pelaksanaan, pengamatan, dan simpulan.

Menurut Priyatni (2014:87) teks prosedur adalah teks yang memberikan petunjuk untuk melakukan atau menggunakan sesuatu dengan langkah-langkah yang urut. Teks prosedur memiliki struktur yang meliputi judul, tujuan, alat dan bahan, tahapan/prosedur. Dengan adanya struktur teks yang lengkap akan membuat seseorang paham dan tertarik untuk membaca teks prosedur tersebut. Rumusan masalah dalam penelitian ini adalah bagaimana struktur teks prosedur, yang meliputi judul, tujuan, bahan/alat, dan tahapan yang ditulis siswa kelas VII SMPN 7 Kota Bengkulu. Tujuan penelitian dalam penelitian ini adalah mendeskripsikan struktur teks prosedur, yang meliputi judul, tujuan, bahan/alat, dan tahapan yang ditulis siswa kelas VII SMPN 7 Kota Bengkulu. Manfaat dalam penelitian ini adalah manfaat secara teoretis dan manfaat secara praktis bagi siswa, guru Bahasa Indonesia, dan sekolah.

\section{METODE}

Metode yang digunakan dalam penelitian ini adalah metode deskriptif dengan pendekatan kualitatif. Data dalam penelitian ini berupa kata-kata atau kalimat dari teks prosedur yang ditulis siswa kelas VII C SMPN 7 Kota Bengkulu yang berjumlah 26 orang. Sumber data penelitian ini adalah teks prosedur yang ditulis siswa kelas VII C SMPN 7 Kota Bengkulu. Teknik pengumpulan data yang digunakan dalam penelitian ini adalah tes esai yaitu menulis teks prosedur dengan menggunakan media gambar dengan tiga topik yang berbeda. Instrumen dalam penelitian ini adalah tes. Teknik analisis data yang digunakan adalah membaca, mengelompokkan, menabulasi, menginterpretasi, dan menyimpulkan. 


\section{HASIL DAN PEMBAHASAN}

\section{Hasil}

Hasil penelitian Analisis Struktur Teks Prosedur Siswa Kelas VII SMPN 7 Kota Bengkulu ini berupa analisis deskriptif. Hasil penelitian disajikan dalam bentuk tabel-tabel rangkuman dan dideskripsikan dalam bentuk pembahasan, keseluruhan data dapat dilihat pada lampiran data. Berdasarkan hasil tes dari 26 siswa yang diberikan tugas menulis teks prosedur dengan menggunakan media gambar dengan topik membuat es kepal milo, membuat nasi goreng, dan membuat piscok meler, terdapat 15 siswa yang memilih topik membuat es kepal milo, 9 siswa yang memilih topik membuat nasi goreng, dan 2 siswa yang memilih topik membuat piscok meler.

Setelah melakukan proses analisis data pada 26 teks prosedur yang ditulis siswa kelas VII C SMPN 7 Kota Bengkulu, telah diketahui bahwa struktur teks yang ditulis sudah lengkap, meliputi judul yang berupa nama benda atau sesuatu yang hendak dibuat dan cara melakukan atau menggunakan sesuatu, tujuan yang berupa paragraf yang menyatakan tujuan penulisan, bahan/alat yang berupa daftar rincian dan paragraf, tahapan yang menggunakan bentuk uraian paragraf dan bentuk penomoran pada setiap langkah.

1. Judul

Judul teks prosedur dapat berupa nama benda atau sesuatu yang hendak dibuat atau dilakukan, dan dapat berupa cara melakukan atau menggunakan sesuatu. Judul yang baik memiliki syarat, yaitu relevan dengan isi tulisan, berbentuk frase, singkat, jelas, bukan kiasan dan tidak mengandung makna ganda. Sebagian besar judul teks prosedur yang ditulis siswa kelas VII C SMPN 7 Kota Bengkulu adalah berupa cara melakukan atau menggunakan sesuatu. Terdapat tiga judul teks prosedur yang ditulis berupa nama benda atau sesuatu yang hendak dibuat atau dilakukan. Contohnya,

Nasi Goreng Murah Meriah

(teks 23)

Terdapat 23 judul teks prosedur yang ditulis berupa cara melakukan atau menggunakan sesuatu. Contohnya,

Cara Membuat Es Kepal Milo Yang Lezat

(teks 1)

Seluruh judul teks prosedur yang ditulis siswa kelas VII C SMPN 7 Kota Bengkulu juga sudah memenuhi syarat judul yang baik yaitu relevan dengan isi tulisan dan ditulis berbentuk frase benda. Semua judul ditulis secara singkat. Contohnya,

Es Kepal Milo

(teks 9)

Semua judul ditulis dengan jelas, bukan kiasan dan tidak mengandung makna ganda. Judul yang ditulis siswa kelas VII C SMPN 7 Kota Bengkulu sudah sesuai dengan teori menurut Priyatni (2014: 87) yaitu judul dalam teks prosedur dapat berupa nama benda atau sesuatu yang hendak dibuat atau dilakukan. Judul dalam teks prosedur juga dapat berupa cara melakukan atau menggunakan sesuatu, dan judul yang ditulis sudah memenuhi syarat judul yang baik sesuai dengan teori menurut Akhadiah dkk. (1988:9) yaitu relevan dengan isi tulisan (sesuai dengan topik atau isi karangan), berbentuk frase (dinyatakan dalam frase benda bukan dalam bentuk kalimat), singkat 
(sesingkat mungkin, pendek, atau ringkas), jelas (mudah dipahami, bukan kiasan dan tidak mengandung makna ganda).

2. Tujuan

Tujuan dalam teks prosedur dapat berupa pernyataan yang menyatakan tujuan penulisan, dan juga dapat berupa paragraf pengantar yang menyatakan tujuan penulisan. Di dalam tujuan biasanya menggunakan pilihan kata yang dapat menarik perhatian seperti "Mudah dibuat atau dilaksanakan" atau "Cepat, bermanfaat, indah, dsb." Seluruh tujuan teks prosedur yang ditulis siswa kelas VII C SMPN 7 Kota Bengkulu berupa paragraf pengantar yang menyatakan tujuan penulisan. Contohnya, Es kepal milo adalah es sangat segar dan cocok diminum di siang hari, es kepal milo juga sangat mudah dibuat dan praktis.

(teks 3)

Seluruh tujuan teks prosedur yang ditulis siswa kelas VII C SMPN 7 Kota Bengkulu juga menggunakan pilihan kata yang menarik perhatian. Terdapat 3 teks yang memuat bagian tujuan menggunakan satu pilihan kata menarik perhatian. Contohnya,

Sangat enak, praktis, mengandung protein, mengandung gizi yang tinggi

(teks 25)

Tujuan yang ditulis siswa kelas VII C SMPN 7 Kota Bengkulu sudah sesuai dengan teori menurut Priyatni (2014:87) yaitu tujuan dalam teks prosedur dapat berupa pernyataan yang menyatakan tujuan penulisan. Dapat juga berupa paragraf pengantar yang menyatakan tujuan penulisan, dan sesuai dengan teori menurut Harsiati dkk. (2017:101) yaitu tujuan dalam teks prosedur merupakan bagian yang menyebutkan apa yang akan dibuat atau dilakukan. Pada bagian ini penulis mencoba menangkap minat pembaca pada produk atau kegiatan yang akan dibuat panduannya, dengan menggunakan pilihan kata yang mampu menarik perhatian.

3. Bahan/Alat

Bahan atau alat dalam teks prosedur dapat berupa daftar atau rincian, dan juga dapat berupa paragraf. Pada teks prosedur tertentu, misalnya melakukan sesuatu, tidak diperlukan bahan/alat. Alat atau bahan dalam teks prosedur dirinci sampai ukuran yang akurat untuk menghasilkan produk yang baik. Sebagian besar bahan/alat teks prosedur yang ditulis siswa kelas VII C SMPN 7 Kota Bengkulu berupa daftar rincian. Terdapat 21 teks yang memuat bagian bahan/alat ditulis berupa daftar rincian. Contohnya,

Bahannya adalah:

1. Milo 3 in 1

2. Coklat bubuk

3. Susu kental manis

4. Air panas

5. Es batu

6. Kacang

7. Meises

8. Milo bubuk

Alatnya adalab:

1. Mangkok kaca

2. Sendok

3. Blender 


\author{
4. Gelas milo \\ 5. Mixer \\ (teks 2)
}

Terdapat 5 teks yang memuat bagian bahan/alat ditulis berupa paragraf. Contohnya, Bahan: 4 siung bawang putih, 3 siung bawang merah, 11 butir cabai rawit, minyak. goreng, telur, nasi, kecap manis, kecap asin, daun bawang, garam Alat: gilingan, spatula, panci, kompor, mangkok, piring saji, garpu, dan sendok. (teks 17)

Terdapat 22 teks yang memuat bagian bahan/alat sebagian ditulis dengan ukuran yang rinci dan akurat sebagian tidak. Contohnya,

Bahan:

1. Milo (satu bungkus)

2. Coklat bubuk (4 sendok makan)

3. Susu kental manis coklat (secukupnya)

4. Air panas (secukupya)

5. Es batu (secukupnya)

Alat:

1. Mangkuk

2. Blender

3. Mixer

4. Cup

(teks 12)

Terdapat 4 teks yang memuat bagian bahan/alat tidak ditulis dengan ukuran yang rinci dan akurat. Contohnya,

Bahannya adalah:

1. Milo 3 in 1

2. Coklat bubuk

3. Susu kental manis

4. Air panas

5. Es batu

6. Kacang

7. Meises

8. Milo bubuk

Alatnya adalah:

1. Mangkok kaca

2. Sendok

3. Blender

4. Gelas milo

5. Mixer

(teks 2)

Terdapat 14 teks yang memuat bagian bahan/alat yang bahan dan alatnya ditulis secara terpisah. Contohnya,

Babannya:

1. Milo (1 bungkus)

2. Coklat bubuk (5 sendok makan)

3. Susu kental manis coklat (1 kaleng) 
4. Air panas (secukupnya)

5. Kacang

6. Es batu

7. Meises

Alatnya:

1. Mangkuk

2. Blender

3. Mixer

4. Сир

(teks 15)

Terdapat 12 teks yang memuat bagian bahan/alat yang penulisan bahan dan alatnya disatukan. Contohnya,

Bahan dan alat:

1. 1 bungkeus milo 3 in 1

2. Coklat bubuk

3. Susu kental manis coklat

4. Air panas

5. Es batu

6. Kacang

7. Meises

8. Milo bubuk

9. Blender

10. Mangkuk

11. Sendok

12. Mixer

13. Сир

(teks 8)

Bahan/alat yang ditulis siswa kelas VII C SMPN 7 Kota Bengkulu sudah sesuai dengan teori menurut Priyatni (2014: 87) yaitu struktur bahan dan alat dalam teks prosedur dapat berupa daftar atau rincian, dapat juga berupa paragraf, namun belum sesuai dengan teori menurut Harsiati dkk. (2017: 102) yaitu alat dan bahan dalam teks prosedur dirinci sampai ukuran yang akurat karena untuk menghasilkan produk yang baik. Bahan/alat yang ditulis belum sesuai dengan teori Harsiati dkk. (2017: 102) karena bahan/alat yang ditulis belum rinci dan akurat.

4. Tahapan

Tahapan dalam teks prosedur harus dengan urutan yang benar. Tahapan dapat berbentuk uraian paragraf menggunakan kata pertama, kedua, ketiga, dan dapat menggunakan bentuk penomoran pada setiap langkah dengan urutan ke bawah. Dan di dalam struktur tahapan terdapat penggunaan kata penghubung waktu, tujuan, urutan dan penggunaan kalimat perintah, saran, dan larangan.

Seluruh tahapan teks prosedur yang ditulis siswa kelas VII C SMPN 7 Kota Bengkulu ditulis dengan urutan yang benar, dan sebagian besar menggunakan bentuk penomoran pada setiap langkah. Terdapat 23 teks yang memuat bagian tahapan ditulis menggunakan bentuk penomoran pada setiap langkah. Contohnya,

Langkah-langkah

1. Masukean satu bungkus milo, coklat bubuk, susu kental manis coklat 
2. Campur rata dengan mixer

3. Tambabkan air panas secukupnya

4. Blender lah es batu sesuai keinginan

5. Masukean semua bahan ke dalam cup

6. Kemudian tambahan toping yang diinginkan seperti kacang, milo bubuk, dan meises (teks 15)

Terdapat 3 teks yang memuat bagian tahapan ditulis menggunakan bentuk uraian paragraf. Contohnya,

Langkah-langkah:

Pertama-tama siapkan air secukupnya dan masukkan terigu secukupnya. Aduk kedua bahan bingga merata. Siapkan kulit lumpia. Tarok, pisang di atas kulit lumpia campurkan meises ceres, coklat bubuk, dan keju parut. Gulung bahan bahan dengan perekat. Kemudian goreng piscok dengan minyak goreng yang panas. Tunggu sampai piscok masak. Dan piscok siap untuk disajikan.

(teks 25)

Di dalam tahapan yang ditulis siswa kelas VII C SMPN 7 Kota Bengkulu terdapat penggunaan kata penghubung waktu, kata penghubung tujuan, kata penghubung urutan, kalimat perintah dan kalimat larangan. Penggunaan kata penghubung waktu terdapat pada 21 teks yang memuat bagian tahapan. Contohnya,

Langkah membuat:

1. Tuangkan air dan terigu secukupnya

2. Aduk air dan terigu sampai tercampur

3. Setelah itu siapkan kulit lumpia

4. Kemudian letakkean pisang di atas kulit lumpia

5. Taburkan meises secukupnya di atas pisang

6. Taburkan juga keju parut

7. Setelab itu lipat kulit lumpia dengan rapi dan berikan perekat (teks 26)

Penggunaan kata penghubung tujuan terdapat pada 1 teks yang memuat bagian tahapan. Contohnya,

Kemudian yang terakbir tuangkan milo bubuk, kedalam cup agar menambah rasa manis. Akbirnya es kepal milo yang enak dan segar siap disajikan dengan nikmat bersama jajanan lainnya

(teks 7)

Penggunaan kata penghubung urutan terdapat pada 2 teks yang memuat bagian tahapan. Contohnya,

Pertama-tama siapkan air secukupnya dan masukkan terigu secukupnya. Aduk kedua bahan bingga merata. Siapkan kulit lumpia. Tarok pisang di atas kulit lumpia campurkan meises ceres, coklat bubuk, dan keju parut.

(teks 25)

Penggunaan kalimat perintah terdapat pada seluruh tahapan teks prosedur yang ditulis siswa kelas VII C SMPN 7 Kota Bengkulu. Contohnya,

Langkah membuat:

1. Tuangkan air dan terigu secukupnya

2. Aduk air dan terigu sampai tercampur

3. Setelab itu siapkan kulit lumpia 
4. Kemudian letakkan pisang di atas kulit lumpia

5. Taburkan meises secukupnya di atas pisang

6. Taburkan juga keju parut

7. Setelah itu lipat kulit lumpia dengan rapi dan berikan perekat (teks 26)

Penggunaan kalimat perintah pada teks yang memuat bagian tahapan, menggunakan akhiran -kan, -i, dan -lah. Contoh partikel akhiran -kan,

Langkah membuat:

1. Tuangkan air dan terigu secukupnya

2. Aduk air dan terigu sampai tercampur

3. Setelab itu siapkan kulit lumpia

4. Kemudian letakekan pisang di atas kulit lumpia

5. Taburkan meises secukupnya di atas pisang

6. Taburkan juga keju parut

7. Setelah itu lipat kulit lumpia dengan rapi dan berikan perekat (teks 26)

Contoh partikel akhiran $-i$,

1. Tuangkan adonan ke dalam cup yang sudah diisikan es batu

2. Setelah itu taburi kacang secukupnya

3. Sesudah menaburi kacang taburi juga meises 1 sendok makan

(Teks 7)

Contoh partikel akhiran -lah,

1. Uleklah/tumbuklah 3 siung bawang putih, 10 siung bawang merah, dan 11 butir cabe rawit, uleklah bingga menjadi balus

2. Aduklah hingga merata

(Teks 21)

Seluruh kalimat perintah diawali dengan kata yang memiliki fungsi predikat. Contohnya,

Tambabkan air panas secukupnya

(teks 1)

Ket

Seluruh kalimat perintah diawali dengan kata yang masuk ke dalam kategori kata kerja

(verba). Contohnya,

Tambabkan air panas secukupnya

Verba Nomina Adverbia (teks 1)

Penggunaan kalimat larangan terdapat pada 1 teks yang memuat bagian tahapan. Contohnya,

Tambabkan susu kental manis, kacang, milo bubuk dan meises secukupnya ke dalam cup (jangan berantakan agar terlibat lebih menarik)

(teks 6)

Tahapan yang ditulis siswa kelas VII C SMPN 7 Kota Bengkulu sudah sesuai dengan teori menurut Priyatni (2014: 87) yaitu struktur tahapan atau prosedur dalam teks prosedur harus dengan urutan yang benar, dan sudah sesuai dengan teori menurut Harsiati dkk. (2017: 102) yaitu langkah dalam teks prosedur bisa disajikan dalam dua 
bentuk, yaitu dalam bentuk uraian paragraf dan dalam bentuk penomoran pada setiap langkah dengan urutan ke bawah. Dalam struktur tahapan atau langkah-langkah teks prosedur juga terdapat penggunaan kata penghubung waktu, tujuan, urutan dan penggunaan kalimat perintah, saran, dan larangan.

\section{PENUTUP}

Sebagian besar judul teks prosedur yang ditulis siswa kelas VII C SMPN 7 Kota Bengkulu berupa cara melakukan atau menggunakan sesuatu, sebagian kecil berupa nama benda atau sesuatu yang hendak dibuat. Judul teks prosedur yang ditulis sesuai dengan syarat judul, yang baik yaitu relevan dengan isi tulisan, berbentuk frase benda, singkat, jelas, dan tidak mengandung makna ganda.

Seluruh tujuan teks prosedur yang ditulis siswa kelas VII C SMPN 7 Kota Bengkulu berupa paragraf pengantar yang menyatakan tujuan penulisan dan menggunakan pilihan kata yang menarik.

Sebagian besar bahan/alat teks prosedur yang ditulis siswa kelas VII C SMPN 7 Kota Bengkulu berupa daftar rincian, sebagian kecil berupa paragraf. Bahan/alat sebagian ditulis dengan ukuran yang rinci dan akurat sebagian tidak, dan tidak ditulis dengan ukuran yang rinci dan akurat. Penulisan bahan/alat secara terpisah dan disatukan.

Sebagian besar tahapan teks prosedur yang ditulis siswa kelas VII C SMPN 7 Kota Bengkulu menggunakan bentuk penomoran pada setiap langkah, sebagian kecil menggunakan bentuk uraian paragraf. Tahapan ditulis dengan urutan yang benar dan di dalam tahapan yang ditulis terdapat penggunaan kata penghubung waktu, kata penghubung tujuan, kata penghubung urutan, kalimat perintah dan kalimat larangan.

\section{DAFTAR RUJUKAN}

Harsiati, Titik dkk. 2017. Bahasa Indonesia Buku Siswa SMP/MTs Kelas VII. Jakarta: Kementerian Pendidikan dan Kebudayaan.

Kosasih, E., dan Kurniawan, Endang. 2018. Jenis-jenis Teks; Fungsi, Struktur, dan Kaidah Kebahasaan. Bandung: Yrama Widya.

Mahsun. 2014. Teks dalam Pembelajaran Bahasa Indonesia Kurikulum 2013. Jakarta: PT Raja Grafindo Persada.

Priyatni, Endah Tri. 2014. Desain Pembelajaran Bahasa Indonesia dalam Kurikulum 2013. Jakarta: PT Bumi Aksara.

Saddhono, Kundharu, dan Slamet, St. Y. 2014. Pembelajaran Keterampilan Berbahasa Indonesia Teori dan Aplikasi. Yogyakarta: Graha Ilmu.

Susetyo. 2014. Menulis Akademik. Bengkulu: Unit Penerbitan FKIP Unib 